\title{
TERORISME NASIONALISTIS A LA BALKANISASI
}

\author{
DOl: https://doi.org/10.33550/sd.v7i1.135 \\ Semy Arayunedya ${ }^{1}$, Semmy Tyar Armandha ${ }^{2}$ \\ ${ }^{1}$ Reformed Center for Religion and Society \\ ${ }^{2}$ Fakultas Ilmu Komunikasi, Universitas Bhayangkara Jakarta Raya
}

\begin{abstract}
The meaning of a word or reality depends on the specific context. Social, economic, political, cultural and ideological backgrounds affect the interpretation of reality. This paper aims to provide a different perspective on the narrative of terrorism which has been narrowed to religious extremism. The formation of narratives is still dominated by the entity of state. Promoted by the state, the attitude of nationalism also has a role in encouraging acts of terrorism. The term balkanization, which originated from the disintegration of the nation-state on the Balkan Peninsula, is also used as a model for instilling nationalism.Elaborated through radical hermeneutics, this paper discusses that acts of terrorism can be carried out through the use of the term balkanization, which is framed in the narrative of nationalism.
\end{abstract} KEYWORDS: balkanization, nationalism, terrorism, radical hermeneutics.

ABSTRAK: Pemaknaan terhadap suatu kata atau realita, pada dasarnya, bergantung pada konteks tertentu. Latar belakang sosial, ekonomi, politik, budaya, serta ideologi mempengaruhi interpretasi pada realita. Tulisan ini bertujuan untuk memberikan sudut pandang yang berbeda pada narasi terorisme yang selama ini identikdengan ekstremisme agama. Narasi mengenai terorisme masih didominasi oleh entitas yang memiliki kekuatan, umumnya oleh negara. Sikap nasionalisme, yang selama ini juga digaungkan dan diusung oleh negara, ternyata memiliki pengaruh dalam aksi terorisme. Istilah balkanisasi, yang bersumber dari perpecahan negara-bangsa di Semenanjung Balkan, juga digunakan sebagai model untuk 
menanamkan nasionalisme. Dikupas dengan hermeneutika radikal, tulisan ini akan menunjukkan bahwa tindakan teroris medapat dilakukan melalui penggunaan istilah balkanisasi yang dibingkai dalam narasi nasionalisme. KATA-KATA KUNCI: balkanisasi, nasionalisme, terorisme, hermeneutika radikal.

\section{Pendahuluan}

Terorisme merupakan sebuah fenomena yang menarik pada beberapa dekade belakangan. Kompleksitas yang terjadi, baik dari sisi aktor yang melakukan maupun tindakan yang dilakukan, mempengaruhi kesulitan untuk merumuskan narasi tunggal bagi fenomena ini. ${ }^{1}$ Namun pada umumnya, Islam diposisikan sebagai faktor utama dan berkembang menjadi narasi tunggal terorisme. Islam digambarkan sebagai kepercayaan radikal yang berkelindan erat dengan terorisme. Islam, khususnya setelah peristiwa 9/11, dianggap sebagai ancaman oleh narasi-narasi di dunia Barat. ${ }^{2}$ Selain Islam, ekstremisme agama juga dapat dijumpai pada kepercayaan Kristen di Amerika Serikat, Zionis di Israel, Hindu di India, Budha di Myanmar, dan beberapa sekte yang dianut oleh kaum milenial di Swiss, Amerika Utara, dan Jepang. ${ }^{3}$ Pemahaman dengan narasi tunggal menjadi bermasalah karena dapat menumbuhkan prasangka buruk, fobia, dan pelabelan terhadap pihak yang selama ini tertuduh.

Sama seperti peristiwa lain yang memiliki multifaktor, terorisme juga demikian. Salah satu ideologi yang jarang mendapat pengamatan sebagai penyebab terorisme adalah nasionalisme. Nasionalisme cukup mendapat tempat mulia sebagai ideologi yang terberi dan baik adanya. Penanaman nasionalisme yang dinarasikan dengan menggunakan contoh apapun akan dianggap wajar. Dalam hal inilah, perpecahan negara-bangsa Yugoslavia di Semenanjung Balkan dijadikan contoh buruk negara yang gagal. Penggunaan istilah Balkanisasi semakin identik dengan pertumpahan darah dan penderitaan panjang yang disampaikan melalui forum-forum diskusi bertemakan kebangsaan atau nasionalisme. Berdasarkan realita tersebut, tulisan ini akan mempertahankan pendirian bahwa pandangan yang menempatkan terorisme yang diidentikkan dengan agama tertentu, nasionalisme yang selalu bermakna positif, dan balkanisasi yang cenderung dimaknai secara

1. Gerard Chaliand dan Arnaud Blin, The History of Terrorism: From Antiquity to Al Qaeda (London: University of California Press, 2007), 2.

2. Bassam Tibi, Islamism and Islam (London: Yale University Press, 2012), 13.

3. Peter Chalk, Non-military Security and Global Order: The Impact of Extremism, Violence, and Chaos on National and International Security, (London: Macmillan Press, 2000), 20. 
peyoratif, merupakan pemahaman yang tidak utuh.

Tulisan ini akan dibagi menjadi empat bagian yang bertujuan untuk memberikan sudut pandang yang berbeda mengenai konsep terorisme, dilihat dari dua aspek penting yaitu nasionalisme dan balkanisasi. Bagian pertama diawali dengan pendahuluan topik dan penggunaan metode untuk menganalisis topik tersebut. Dilanjutkan bagian kedua yang menjabarkan perkembangan konsepsi terorisme, nasionalisme, dan balkanisasi. Pengupasan berikutnya menggunakan hermeneutika radikal terhadap konsepsi terorisme yang selama ini didefinisikan. Dalam bagian ini, aspek nasionalisme serta balkanisasi turut dijelaskan sebagai dua instrumen yang menjadi suplemen bagi konstruksi terorisme. Pada bagian akhir melakukan sintesis yang menemukan konsepsi terorisme nasionalistis a la balkanisasi.

\section{Metode Analisis}

Tulisan ini berupaya melakukan dekonstruksi pada makna yang selama ini dinarasikan secara tunggal. Dekonstruksi adalah sebuah cara berpikir yang ditawarkan oleh Jacques Derrida untuk mempersoalkan keutuhan dan pemahaman makna sehingga praktis mengkritik tradisi dan otoritas, atau yang lebih familiar disebut Derrida sebagai teks. ${ }^{4}$ Derrida memandang realita sebagai teks, yang berarti bahwa realita memiliki pemaknaan dibaliknya, dan pemaknaan tersebut sifatnya plural. Derrida memandang bahwa setiap teks atau realita memiliki kontradiksinya tersendiri, yang jika ditemukan, akan meruntuhkan seluruh bangunan teks atau realita tersebut. Proses berpikir ini disebut sebagai dekonstruksi karena berupaya meruntuhkan konstruksi atau bangunan yang selama ini dianggap telah mapan dan diterima secara umum oleh khalayak. Namun demikian, unsur normatif dari filosofi dekonstruksi, yang memaknai pluralitas kebenaran, tidak menjadi penekanan dalam tulisan ini.

Dekonstruksi adalah salah satu varian dari hermeneutika, namun lebih radikal daripada varian lain. Hermeneutika, pada umumnya, bertujuan untuk memahami susunan makna teks, baik untuk merehabilitasi makna asli ataupun mengkonstruksi makna baru. Namun, hermeneutika radikal mengingkari tujuan tersebut karena radikal merujuk pada teks yang otonom dan terbuka untuk diinterpretasi tanpa batas. Hermeneutika radikal bergulat pada makna yang tidak pernah diputuskan. ${ }^{5}$ Untuk selanjutnya, dekonstruksi akan disebut hermeneutika radikal.

4. F. Budi Hardiman, Seni Memahami: hermeneutik dari Schleirmacher sampai Derrida, (Yogyakarta: Kanisius, 2015), 274.

5. Ibid., 296. 
Hermeneutika radikal menyoroti oposisi biner, yakni sepasang kata yang memiliki makna berlawanan, lalu menunjukkan keunggulan salah satu makna. Pria/wanita, rasional/emosional, kuat/lemah, baik/jahat adalah beberapa contoh dari oposisi biner. Makna yang dianggap lemah atau tidak diunggulkan merupakan pusat perhatian dari hermeneutik radikal. Hermeneutika radikal dilakukan dengan dua langkah. Pertama, ialah dengan membalikkan lalu menekankan kutub lawannya (hal yang dipandang lebih rendah atau yang negatif), alih-alih membiarkan dominasi dari salah satu kutub. Misalnya, oposisi biner rasional/emosional lalu dibalikkan jadi emosional/ rasional. Dengan demikian, dapat ditunjukkan kandungan makna dan interpretasi lain dari kutub yang selama ini dianggap lebih lemah, yaitu emosional. Setelah itu, dapat diketahui seluruh makna teks didikte oleh oposisi biner tersebut. Langkah kedua adalah dengan menghapus pemikiran biner sehingga istilah-istilah tersebut tidak dipikirkan dan terjebak dengan logika biner.

Dalam hal ini, hermeneutika radikal digunakan untuk melihat bagaimana oposisi biner begitu mudah dikonstruksi sehingga dapat menarasikan terorisme yang kemudian dapat dengan efektif digunakan untuk arah atau kepentingan tertentu. Ditarik dari kerangka berpikir tersebut, tulisan ini menyuguhkan makna terorisme yang berbeda Artinya, rezim pemaknaan terhadap oposisi biner dalam terorisme akan ditangguhkan, sehingga kita dapat melihat pemaknaan mengenai apa yang terpinggirkan dan apa dampaknya terhadap praktik sosial di masyarakat

\section{Ragam Kepentingan dalam Terorisme}

Terorisme merupakan salah satu kata yang hingga saat ini tidak berhenti diperdebatkan karena belum menemukan kesepakatan, setidaknya di antara para akademisi. Alex Schmid, seorang pakar studi terorisme, membedah masalah ini dan menyajikan 109 definisi terorisme yang berbeda. Beberapa waktu kemudian, Schmid dan Easson menyusun 260 definisi yang berbeda dalam sebuah buku tentang terorisme, tetapi masih tidak dapat menunjukkan konsensus secara universal. ${ }^{6}$

Salah satu faktor sulitnya mendefinisikan terorisme adalah karena makna kontekstual dari istilah tersebut telah berubah begitu signifikan selama dua ratus tahun terakhir. Istilah mula-mula teror ditemui ketika peristiwa kekerasan politis terjadi dari rezim Jacobin dan Thermidorian di Perancis. ${ }^{7}$ Terorisme yang mulai dikenal pada peristiwa Revolusi Perancis

6. Ofir Falk, "Terrorism: Agreeing on the Basics," American Diplomacy, 1 Mei 2019, diakses pada 12 Desember 2019, http://americandiplomacy.web.unc.edu/2019/05/ terrorism-agreeing-on the-basics-2/.

7. Ariel Heryanto, State Terrorism and Political Identity in Indonesia: Fatally Belonging (New York: 
berfokus dari kekerasan yang dirancang negara untuk menimbulkan ketakutan dan teror, sekarang digambarkan sebaliknya, yaitu kekerasan politik yang diarahkan kepada negara. Konvensi Perserikatan Bangsa-Bangsa (PBB) tahun 1937 menyatakan bahwa terorisme adalah segala bentuk tindakan kejahatan yang ditujukan langsung kepada negara, dengan maksud menciptakan teror terhadap orang-orang tertentu atau kelompok orang atau masyarakat luas.

Istilah terorisme mulai mengemuka pada tahun 1980an ketika pemerintahan Reagan mendeklarasikan terorisme adalah salah satu musuh terbesar Amerika Serikat. Sejak saat itu, istilah terorisme menjadi konsumsi publik yang jauh lebih terdengar dari masa sebelumnya. Tentu, meskipun terorisme menjadi kata yang mulai umum tetapi perbincangan mengenai terorisme tidak menjadi sebuah percakapan publik secara konstan. Perbincangan mulai serius ketika terjadi serangan bunuh diri di New York pada 11 September 2001 dan pengeboman Bali pada 12 Oktober 2002. ${ }^{8}$

Namun demikian, belum ada kesepakatan universal, karena setiap negara menggunakan definisinya masing-masing. ${ }^{9}$ Definisi terorisme tergantung pada kepentingan suatu negara. ${ }^{10}$ Perbedaan tersebut tentu bukan tanpa dasar karena masing-masing negara memiliki medan pertempuran dengan konteks politik, sosial, ekonomi dan budaya yang berbeda. Setiap negara memiliki persepsi dan perspektif yang berbeda satu sama lain, dengan kesulitan utama pada saat menentukan siapa "orang baik" dan "orang jahat" nya. ${ }^{11}$ Sangat sulit menentukan apakah aksi terorisme hanya berhenti pada penyerangan terhadap warga sipil, ataukah juga mencakup serangan terhadap militer. Namun, jika melihat pada fenomena kontemporer, predikat teroris dapat disematkan pada angkatan bersenjata suatu negara. Amerika Serikat dan Iran yang masih terlibat konflik, saling menyematkan label pada angkatan perang lawannya sebagai teroris. ${ }^{12} \mathrm{Hal}$ ini juga menunjukkan pelekatan predikat teroris juga ada yang bersifat

Routledge, 2006), 161.

8. Ibid.

9. Myra Williamson, Terrorism, War and International Law: the Legality of the Use of Force Against Afghanistan in 2001 (Aldershot: Ashgate Publishing Ltd., 2009), 38.

10. Bruce Hoffman, Inside Terrorism (New York: Columbia University Press,1998), 23.

11. Sean Larkin, "Why Can't We Agree on a Definition of Terrorism?," Open Mind BBVA, 16 Desember 2013, diakses pada 10 Maret 2020, https:/www.bbvaopenmind.com/en/economy/ geopolitics/why-cantwe-agree-on-a-definition-of-terrorism/.

12. Lesley Wroughton, "In unprecedented move, U.S. names Iran's Revolutionary Guards a terrorist group," Reuters, 8 April 2019, diakses pada 10 Maret 2020, https:/fr.reuters.com/article/topNews/ idUKKCN1RK1NQ; AFP, "Iran Masukkan AS ke Dalam Daftar Teroris usai Bunuh Soleimani," CNN Indonesia, 7 Januari 2020, diakses pada 10 Maret 2020, https://www.cnnindonesia.com/internasional/ 20200107160325-120-463175/iran-masukkan -as-ke- dalam-daftar-teroris-usai-bunuh-soleimani. 
politis.

Menilik pada realita tersebut, dapat dikatakan bahwa persoalan terorisme begitu kompleks dan bersifat partikular yang merujuk pada suatu konteks. Namun demikian, terdapat suatu pola yang menunjukkan bahwa negara, sebuah entitas tertinggi yang memiliki kekuatan dan kekuasaan, begitu berpengaruh dalam menentukan definisi terorisme dan siapa pelakunya. Di samping memiliki kedaulatan penuh, baik ke luar maupun ke dalam negeri, negara juga merupakan satu-satunya entitas yang memiliki instrumen dan mekanisme paling efektif melawan siapa saja yang dianggap sebagai teroris. ${ }^{13}$ Bahkan beberapa negara juga dianggap mensponsori gerakan terorisme seperti Amerika Serikat dan Iran yang saling memberi label teroris, India yang melabeli Pakistan sebagai teroris, dan sebagainya. ${ }^{14}$

Penggunaan narasi terorisme telah menjadi sebuah diskursus di kalangan pemimpin negara. Para pemimpin telah menyuguhkan terorisme ke publik sebagai sebuah drama moral yakni pertentangan antara yang baik dan jahat dalam sebuah pertarungan di dalam masyarakat. Deklarasi publik dari seorang presiden George Bush yang menyatakan bahwa Amerika menghadapi peperangan jenis baru, yakni terorisme, berperan sentral dalam perbincangan internasional mengenai terorisme. ${ }^{15}$

\section{Menangguhkan Oposisi Biner dalam Terorisme}

Setelah peristiwa 9/11, bendera Amerika Serikat terlepas dari rak-rak dan muncul di mana-mana, antara lain di mobil, gedung, kaus, dan bahkan di kulit sebagian masyarakat dalam bentuk tato. Spanduk, poster, kemeja, dan papan iklan menyatakan "United we stand", "Bangga menjadi orang Amerika," dan "God Bless America" bermunculan. Logo-logo perusahaan dengan cepat dipasang kembali dalam warna-warna patriotik merah, putih, dan biru yang dikaitkan dengan peristiwa 9/11. ${ }^{16}$

Pihak politisi, yang juga menampilkan diri sebagai penyelamat, menimbulkan paranoia budaya dengan bermacam slogan "perang melawan teror", "kami melawan mereka", "perang mereka melawan kita", "baik versus kejahatan". Lebih jauh lagi, respons masyarakat terhadap peristiwa 9/11,

13. Adrian Guelke, Terrorism and Global Disorder: Political Violence in The Contemporary World, ( New York:Palgrave Macmillan, 2006), 190-191.

14. Mateen Haider, "RAW Involved in Terrorist Activities Across Pakistan: Foreign Secretary," Dawn, 14 Mei 2015, diakses pada 1 Maret 2020 https://www.dawn.com/news/1181908.

15. Carol Winkler, In the Name of Terrorism: Presidents on Political Violence in the Post-World War II Era (New York: State University of New York, 2006), 189.

16. Kristina Kočan Šalamon, “Public Response to 9/11 in Politics: Patriotism, Fear, and, Language Issues“ Informatologia 51, no. 1/2 (2018): 35. 
ketika para politisi dan kemudian media mempresentasikan keistimewaan, demokrasi, kebebasan, kemakmuran, dan konsumerisme Amerika sebagai kebajikan Amerika terbesar, menggunakan bahasa yang secara ideologis justru memecah belah. ${ }^{17}$

Gagasan untuk menyebarkan ketakutan di sisi politik telah disajikan dalam berbagai studi. Cakupan terorisme telah dibawa ke dalam diskursus ketakutan yang luas sehingga berkontribusi pada munculnya politik ketakutan. Hal ini mempengaruhi para pengambil kebijakan mengasumsikan bahaya, risiko, dan ketakutan untuk mencapai tujuan tertentu. Beberapa sarjana, termasuk Phillip Wander, yang menciptakan istilah 'dualisme kenabian' pada tahun 1984, menyebut jenis retorika yang memecah belah ini membagi dunia menjadi dua bagian, yaitu menjadi baik dan jahat, menjadi kita dan mereka seperti yang dilakukan Presiden Bush setelah serangan-serangan itu. Dualisme kenabian adalah narasi kebijakan luar negeri yang bersifat moralistik yang membagi dunia menjadi dua kekuatan yang saling berlawanan dari "baik" dan "jahat" dan menegaskan superioritas yang diberikan Tuhan pada Amerika atas musuh yang "jahat"18

Untuk memahami hirarki oposisi biner dalam terorisme, maka pasangan makna harus dibalik, yakni jahat dan baik. Pembacaan Derrida mengenai 9/11 memberikan sudut pandang yang meminati makna yang terpinggirkan, dalam hal ini adalah "jahat". Derrida mengajak untuk membaca peristiwa 9/11 sebagai krisis yang telah dan akan menempuh beberapa tahap. ${ }^{19}$ Tahap pertama adalah masa Perang Dingin sebagai titik pijak dari peristiwa 9/11. Para pembajak yang "jahat" ini adalah hasil binaan dari Amerika Serikat selama Uni Soviet menginvasi Afganishtan di masa Perang Dingin. Persenjataan dan agen intelijen Amerika Serikat memegang peranan penting terhadap para pejuang Islam Afganishtan di awal 1980an hingga mereka memerintah Afganishtan.

Tahap kedua, Derrida menyoroti kekuatan yang tidak berimbang di antara pasangan yang berlawanan ini. Teroris yang "jahat" ini tidak dapat diperhadapkan dengan negara. Ketika Perang dingin dikarakteristikkan dengan dua kekuatan yang berimbang, yakni antara dua negara adikuasa maka adalah tidak mungkin pada masa selanjutnya membandingkan negara dengan terorisme yang tidak berasal dari negara. Terorisme nonnegara tidak dapat dihitung kekuatannya. Presiden George W. Bush pernah menuduh beberapa negara yang sengaja menyembunyikan teroris. Pernyataan tersebut

17. Ibid., 37.

18. Ibid., 36.

19. Giovanna Borradori, Philosophy in a Time of Terror: Dialogue with Jurgen Habermas and Jacques Derrida, ( London: University of Chicago Press, 2003), 150. 
justru menunjukkan pandangan Amerika Serikat dalam penolakannya terhadap kekuatan pasukan teroris nonnegara yang tidak dapat dibandingkan dengan kekuatan negara. ${ }^{20}$ Masih di tahap ini, Derrida melihat penamaan dan monumentalisasi 9/11 semakin mengingatkan penyerangan itu. Monumen peringatan tersebut justru memperuncing peperangan antara media Barat dengan teroris nonnegara. Hal ini berhubungan dengan tahap selanjutnya, yakni tahap keempat yang disebut lingkaran setan. Lingkaran ini bekerja dengan represi yang tidak terputus dan berulang. Pendeklarasian perang melawan terorisme justru seperti bumerang yang pada akhirnya kembali menghantam koalisi negara-negara yang tergabung dengan Amerika Serikat. Di situ, lingkaran setan terus berputar.

Dikte logika biner antara jahat dan baik menjadi dominan di dalam pemikiran terorisme. Logika ini perlu ditangguhkan agar tidak terjebak pada dikte yang dominan. Hal ini akan membuka kemungkinan interpretasi terhadap jenis terorisme yang lain. Tidak hanya identik dengan ekstremisme agama, terorisme menautkan dirinya pada bermacam-macam motif ideologi lain seperti sindikalisme, anarkisme, dan nasionalisme.

Sindikalisme merupakan ajaran revolusioner yang menggunakan para pekerja sebagai kontrol terhadap ekonomi dan pemerintahan. Kelompok-kelompok ini juga seringkali melakukan kudeta berdarah untuk menggulingkan pemerintahan. The Revolutionary Armed Forces of Colombia (FARC) dan The National Liberation Army (ELN) menjadi salah satu contoh terorisme di Kolombia. Kekerasan yang terjadi pada rentang tahun 1948-1958 menewaskan 200.000 orang. Dalam kurun waktu tersebut, kelompok itu menggunakan ideologi komunis dan menggunakan taktik perang gerilya untuk mengonfrontasi pemerintah. ${ }^{21}$ FARC mengusung reforma agraria, reformasi di tubuh militer, dan pemerintahan lokal yang berdaulat sedangkan ELN menentang ekstraksi minyak dan investasi yang dilakukan oleh perusahaan multinasional asing.

Paham lain yang terkait erat dengan aksi teroris adalah anarkisme. Anarkisme merupakan ajaran yang menentang segala bentuk kekuasaan negara termasuk aparat dan undang-undang negara. Pada akhir abad ke-19 dan awal abad ke-20, sebelum Perang Dunia I, terorisme sering disematkan pada kaum anarkis dan revolusioner sosial sayap kiri. Untuk mencapai tujuannya, para anarkis menggunakan propaganda kekerasan dengan melakukan pembunuhan terhadap tokoh-tokoh politik. ${ }^{22}$

20. Ibid., 151.

21. Zachary Toll, "The Revolutionary Armed Forces of Colombia and National Liberation Army" Journal of Mason Graduate Research 4, no. 1 (2017): 16.

22. Guelke, 190. 
Nasionalisme juga tidak luput menjadi bagian dari terorisme. Sejak perang dunia kedua, label teroris mulai disematkan oleh penguasa koloni pada para pejuang nasionalisme yang menuntut kemerdekaan. ${ }^{23}$ Pergerakan nasionalis dianggap berbahaya karena merongrong kekuasaan. Setelah perang dingin usai, hampir tidak ada perang maupun penjajahan antarnegara sehingga mempengaruhi perkembangan konsep nasionalisme, khususnya pengaruhnya terhadap terorisme.

Dalam diskursus itulah, diskusi keamanan internasional bergulat dengan pertanyaan apakah negara dapat melakukan tindakan terorisme dan sebaliknya juga apakah seorang pejuang kemerdekaan yang berjuang melawan rezim penindas termasuk dalam golongan teroris? ${ }^{24}$

\section{Gelombang Nasionalisme}

Sistem negara modern yang diakui internasional muncul sejak Kongres Munster (1644-1648) dan Osnabriick (1645-1648) kemudian diratifikasi dalam perjanjian Westphalia (1648). ${ }^{25}$ Perjanjian ini berusaha mengakhiri perang berpuluh-puluh tahun antara negara penganut Protestan dan Katolik. Popularitas pemikiran Gereja Abad Pertengahan mulai menurun dan digantikan oleh pemikiran Modern. Perkembangan sistem negara modern selanjutnya semakin menemukan bentuknya di tengah pemikiran modern tentang rasionalitas.

Selain itu, sistem negara model Westphalian menjadi simbol transformasi tatanan politik yang semula hirarki berubah menjadi anarki. Transformasi tatanan itu menjadi penanda berubahnya era dunia baru yang tidak lagi terpusat pada Paus, Gereja, dan Kerajaan melainkan rakyat dan individu. Penolakan dan pemberontakan terhadap sistem hirarki dalam pemerintahan memunculkan negara-negara baru dengan kedaulatan teritorial masing-masing negara, kesetaraan antarnegara, dan bebas dari ancaman dari negara lain. Sistem negara model Westphalia memiliki karakteristik kedaulatan terirorial yang merdeka dan tidak ada yang mendikte bagaimana negara-negara berelasi satu sama lain. ${ }^{26}$ Sesudah Perjanjian Westphalia inilah, nasionalisme perlahan-lahan lahir.

Revolusi Perancis merupakan peristiwa penting dalam sejarah manusia yang menawarkan rasio untuk menentukan nasib dan mengatur diri sendiri. Masyarakat pada waktu itu dipengaruhi oleh pemikiran yang menekankan

\section{Ibid.}

24. Falk, "Terrorism: Agreeing on the Basics."

25. Jeremy Larkins, From Hierarchy to Anarchy: Territory and Politics before Westphalia (London:Palgrave Macmillan, 2010), 3.

26. Ibid. 
keraguan untuk mendapat sebuah jawaban yang pasti. Keraguan, dan bukan iman kepercayaan, harus ditempatkan sebagai praanggapan apabila manusia ingin menyelidiki sesuatu. Logika menjadi perangkat khas Abad Modern yang membangun sebuah idealisme untuk menentukan nasib sendiri (self determination) dari sebuah bangsa. ${ }^{27}$ Rasio telah menjadi alat legitimasi bagi otoritas negara di lingkungan masyarakat modern yang membentuk sebuah gagasan nasionalisme.

Para sejarawan lain menyepakati bahwa konsep gagasan nasionalisme mulai menemukan bentuknya sejak Revolusi Amerika kemudian mempengaruhi Revolusi Prancis hingga reaksi berbagai negara seperti Prussia, Rusia, dan Spanyol terhadap usaha penaklukan dari Kaisar Napoleon Bonaparte..$^{28}$ Rentang sekitar 40 tahun itu adalah periode pembentukan gagasan nasionalisme. Revolusi Perancis seringkali dinilai sebagai kelahiran gagasan modern tentang nasionalisme dengan penekanan pada rakyat yang memiliki hak untuk memerintah dirinya. ${ }^{29}$

Selanjutnya, gelombang nasionalisme menyebar ke bagian Eropa lainnya yakni Serbia, Yunani, Polandia serta di antara elit Amerika Latin, dari tahun 1810 hingga 1820-an. Gelombang besar pertama memuncak dalam Revolusi 1848 di Eropa - yang disebut 'musim semi rakyat (Spring of Peoples)' - dan pencapaian utamanya adalah penyatuan Jerman dan Italia, di bawah naungan Prussia dan Piedmont, dan peningkatan Hongaria dalam kekaisaran Habsburg. Pada akhir abad ke-19, gelombang nasionalisme kedua berkembang di Eropa Timur dan Utara antara lain Ceko, Slovakia, Rumania, Bulgaria, Lituania, Finlandia, Norwegia, Yahudi. Gerakan nasionalisme di luar Eropa antara lain di Meiji-Jepang, India, Armenia, dan Mesir merupakan gelombang ketiga. Gelombang terakhir yang segera bergabung dalam dekade pertama abad kedua puluh mewabah ke Asia yakni Turki, Arab, Persia, Burma, Jawa, Filippina, Vietnam, dan Cina. Arus gelombang terakhir ini juga merupakan gerakan nasionalisme pertama di Afrika yang meliputi Nigeria, Ghana, dan Afrika Selatan. Pada 1930-an dan 1940-an, hampir seluruh sudut dunia terpapar oleh gerakan nasionalisme. ${ }^{30}$

Dalam pengamatannya, Anthony Smith sering mendapati nasionalisme di suatu negara juga terbentuk tanpa adanya bangsa terlebih dulu. Pembentukan ini terjadi pada masa setelah dekolonisasi di Afrika dan Asia. Tanzania, Nigeria, dan Indonesia merupakan beberapa contoh sebuah

27. Anthony D. Smith, Nationalism: Theory, Ideology, History $2^{\text {nd }}$ ed (Cambridge: Polity Press, 2010), 58-59.

28. Ibid., 95.

29. Paul Lawrence, Nationalism, History, and Theory (New York: Routledge, 2014), 25.

30. Smith, Nationalism: Theory, Ideology, History, 95. 
negara tanpa bangsa ${ }^{31}$. Nasionalisme di negara-negara tersebut dibentuk tidak sebatas pada mengupayakan kemerdekaan atau kedaulatan politik. Para pejuang nasionalisme negara tanpa bangsa, juga membentuk kebudayaan suatu masyarakat. Pergerakan nasionalisme diarahkan untuk membangun tatanan kebudayaan ideal sebagai identitas nasional.

Walaupun nasionalisme lahir dari modernisme yang sekular, akan tetapi nasionalisme lebih mirip sebagai agama politik daripada ideologi politik. Agama adalah sebuah sistem kepercayaan dan praktik yang terpadu terhadap hal-hal sakral, yaitu hal-hal yang ditetapkan dan dilarang. Sebuah kepercayaan dan praktik-praktik yang menyatu dalam satu komunitas moral tunggal. ${ }^{32}$

Pendekatan fungsional ini berguna untuk memahami agama sebagai pengganti nasionalisme, seperti halnya Durkheim sendiri menekankan pada peran sakral dan ritual. Nasionalisme mengadakan upacara peringatan bagi para pemimpin besar atau bagi rakyat yang gugur dalam pertempuran, yang mengorbankan hidup mereka untuk negara mereka. Upacara- upacara peringatan ini bermunculan di berbagai negara termasuk Amerika Serikat, Inggris, Italia, Turki dan Rusia. Pada saat-saat seperti itu, kita dapat memahami bahwa sebuah bangsa adalah persekutuan warga yang sakral. Sebuah karakter yang sesuai dengan interpretasi nasionalisme sebagai agama pengganti.

Agama nasionalisme negara-negara baru di Asia dan Afrika melahirkan juga para pemimpin yang menyandang nabi sekaligus juruselamat rakyat. Nehru, Sukarno, Nkrumah, dan Kenyatta dipercaya membawa era baru dalam kebebasan dan keadilan. ${ }^{33}$ Harapan itu melatarbelakangi nasionalisme yang begitu dielu-elukan anak-anak muda yang gelisah, para intelektual yang terpinggirkan, dan di kemudian hari kelompok masyarakat yang tertindas di Afrika dan Asia. Nasionalisme adalah sebuah mimpi yang ingin dicapai, tetapi diraih dengan kekerasan dan penderitaan yang tidak terkatakan. Puncaknya dapat disaksikan pada periode Perang Dunia Pertama, Nazisme, dan genosida Perang Dunia Kedua. ${ }^{34}$

Dalam konteks tersebut, peristiwa di Semenanjung Balkan menjadi sebuah model untuk membangkitkan spirit nasionalisme. Balkanisasi dipandang antitesis bagi persatuan bangsa. Di Indonesia, setidaknya para akademisi sosial-politik pernah meramalkan bahwa Indonesia akan mengalami balkanisasi menjadi negara gagal yang terpecah-pecah pada waktu

31. Ibid., 10.

32. Ibid., 38 .

33. Ibid., 39.

34. Ibid., 95. 
transisi Orde Baru ke Reformasi. ${ }^{35}$

\section{Merunut Peristiwa di Semenanjung Balkan}

Pada abad ke-19, kawasan di Semenanjung Balkan dikuasai oleh Imperium Ottoman. ${ }^{36}$ Di sisi lain, Imperium Rusia berupaya untuk mengambil alih sehingga terjadi peperangan yang berkepanjangan. Bangkitnya nasionalisme di Eropa Barat mendorong bangkitnya nasionalisme di Balkan yang didiami oleh bangsa Slavic. Gerakan nasionalisme untuk mempersatukan Balkan ini disebut sebagai Pan-Slavisme. Imperium Ottoman yang merasa terancam akan gerakan ini, kemudian mulai mengadu domba negara-negara yang mendukung persatuan Balkan tersebut melalui jalur religius, yaitu dengan mendirikan gereja ortodoks di Bulgaria. Bangsa Slav kemudian melakukan perlawanan terhadap Imperium Ottoman pada 1875. Ottoman yang tidak tinggal diam, kemudian menekan habis-habisan perlawanan tersebut dengan mengorbankan begitu banyak jiwa termasuk wanita dan anak-anak. Tidak terima dengan manuver Ottoman tersebut, Rusia kemudian melancarkan serangan terhadap Ottoman pada 1877-1878, yang pada akhirnya memenangkan Rusia.

Kekalahan Ottoman disusul oleh Perjanjian San Stefano pada 1878, yang menghentikan kendali Ottoman atas Balkan. Perjanjian tersebut memberikan kemerdekaan kepada Bulgaria, Serbia, Romania, Montenegro, dan Bosnia-Herzegovina. Rusia juga memperoleh lahan luas yang strategis. Namun demikian, perjanjian ini justru membuat resah Eropa Barat yang khawatir Rusia semakin kuat. Kanselir Jerman Otto von Bismarck kemudian menggagas Kongres Berlin untuk meninjau kembali hasil Perjanjian San Stefano yang dianggap mengkhawatirkan jagat Eropa Barat tersebut. Ia membentuk "Dreikaiserbund"; sebuah aliansi antara Jerman, Rusia, dan Austria-Hungaria untuk mewujudkan kongres tersebut. Hal ini dianggap urgen karena Rusia dan Austria semakin memanas hubungannya pasca Perjanjian San Stefano. Pihak-pihak yang paling merasa berkepentingan untuk menguasai Semenanjung Balkan adalah Rusia, Ottoman, dan Ausria-Hungaria. Sementara itu, pihak yang merasa terancam oleh penguasaan Rusia atas Balkan adalah Inggris yang lebih menginginkan Ottoman berkuasa untuk mengimbangi pengaruh Rusia di Laut Hitam. Jerman menjadi pihak netral yang memiliki kepentingan semata agar terjadi keseimbangan kekuatan dan stabilitas di kawasan Eropa. Bertolak belakang dengan itu semua,

35. Wasito Raharjo Jati. "Mengurai Gagasan Negara Pascakolonial: Kontekstualisasi Indonesia Sebagai Negara Dunia Ketiga" Masyarakat Indonesia 39, no. 1 (2013): 151.

36. Gloria Lotha, "Congress of Berlin”, Britannica, diakses pada 7 Februari 2020, https://www.britannica.com/event/Congress-of-Berlin. 
negara-negara Balkan menginginkan otonomi penuh dengan membentuk satu negara yang kuat dan mandiri, yang lepas dari pengaruh Ottoman, Rusia, ataupun Austria-Hungaria.

Perjanjian Berlin ditandatangi sebagai hasil dari Kongres yang dilangsungkan pada 13 Juni hingga 13 Juli 1878 tersebut. Isi kesepakatan San Stefano hanya diterima 11 dari 29 yang ada. Hasilnya adalah (1) kemerdekaan penuh bagi Romania, Serbia dan Montenegro; (2) Bulgaria menyerahkan dua daerahnya yaitu Rumelia Timur dan Makedonia kembali ke Ottoman; (3) teritori Ottoman yang diberikan kepada Rusia pada Perjanjian San Stefano diakui oleh negara lain, kecuali Kota Bayazid dan Lembah Alashkerd; (4) wilayah Bosnia diambil alih oleh Imperium Austria-Hungaria, serta diperolehnya basis militer di Sanjak Novi Pazar. Perjanjian ini pada kelanjutannya justru membuat hubungan antar peradaban di dalamnya semakin rumit. Hal ini karena Perang Dunia I justru terjadi diawali dari kemelut yang terjadi di kawasan Balkan.

Kongres Berlin pada 1878 adalah tempat di mana pertama kali istilah Balkanisasi mulai menguasai diskursus politik. ${ }^{37}$ Pada Kongres tersebut, terdapat begitu banyak kepentingan yang bertemu dalam satu forum. Seperti yang telah dijabarkan sebelumnya, Kongres Berlin merupakan sebuah kanal kepentingan antara para imperium untuk memperebutkan beberapa peradaban di negara maupun etnis yang berada di kawasan Balkan seperti Bulgaria, Serbia, Romania, Montenegro, dan lainnya. Di sisi lain, negaranegara Balkan tersebut menolak menjadi perebutan imperium yang sama sekali tidak sedarah atau seetnis dengan mereka. Negara Balkan berupaya menjadi independen dan otonom seutuhnya, namun direpresi oleh para imperium.

Berdasarkan fakta sejarah tersebut, Grubacic melihat bahwa Balkanisasi memiliki dua bentuk yang saling menegasi satu sama lain. ${ }^{38}$ Balkanisasi dapat terjadi dari atas dan juga dari bawah. Balkanisasi dari atas adalah kondisi di mana kekuatan dan kekuasaan sebuah entitas politik yang berupaya memecah-belah suatu peradaban, baik negara-bangsa maupun kelompok etnis yang sudah ada. Balkanisasi dari bawah, secara kontras, merupakan upaya membentuk suatu peradaban secara kolektif agar dapat menentukan nasibnya sendiri. Berdasarkan dinamika konflik di Balkan dari masa imperium, masa Perang Dunia, hingga masa akhir Perang Dingin, maka dapat dikatakan terjadi Balkanisasi dari bawah maupun Balkanisasi dari atas. Namun demikian, diskursus di atas jarang menjadi latar belakang

37. Andrej Grubacic. "Balkanization of Politics, Politics of Balkanization" Globalizations 9, no. 3 (2012): 442 .

38. Ibid. 
terjadinya peristiwa separasi di negara-bangsa Yugoslavia. Ekses pemisahan negara yang berakibat peperangan, penderitaan, dan pertumpahan darah dijadikan model untuk menebar ketakutan.

\section{Terorisme dalam Bingkai Nasionalisme dan Balkanisasi}

Dalam buku Paranoia Switch, Stout mengamati masalah teror dan ketakutan dalam masyarakat Amerika dari sudut pandang neuropsikologis. ${ }^{39}$ Dia memunculkan istilah limbic war, yakni perjuangan destruktif oleh sekelompok kader yang memperbesar pengaruhnya dengan menggunakan kecemasan kolektif masyarakat. Stout menggambarkan enam tahap limbic war. Tahap pertama biasanya perang atau serangan, diikuti oleh trauma kelompok merupakan peristiwa traumatis yang menanamkan ketakutan tanpa sadar di benak warga negara. Tahap kedua melibatkan agen-agen yang menebar rasa takut dengan menggunakan ketakutan publik untuk mengejar agenda pribadi. Para agen ini berperan menjaga kekuasaan dan mengontrol keadaan. Seperti yang ditunjukkan Stout, mereka mengingatkan masyarakat secara intens dan dramatis tentang seberapa besar bahaya yang dihadapi. Ancaman yang ada merupakan hal yang signifikan atau bahkan nyata. Orang-orang yang mengalami trauma kembali dan merasa takut cenderung mencari perlindungan pada seseorang, yang secara bersamaan mengumumkan bahaya dan sekaligus dirinya sebagai pelindung. Menurut Stout, tahap ini sangat penting, karena merupakan indikator yang menentukan keberlanjutan limbic war - yaitu apakah masyarakat memutuskan untuk mengikuti para agen ketakutan atau tidak.

Tahap ketiga disebut scapegoatism, dimana para pemimpin menyalahkan kelompok atau ras lain sebagai penyebab krisis dan menggunakan racun kebencian sebagai medium. Selama scapegoatism, sekelompok orang yang diduga bersalah, walaupun hanya bersinggungan secara simbolis saja, terkait dengan bencana yang membuat trauma bangsa pada tahap pertama selalu menjadi kambing hitam. Setelah kambing hitam ditentukan, baru memasuki tahap keempat yakni menuntut pembalasan dan menyebabkan intoleransi. Atmosfer pada tahap ini sudah melahirkan narasi "kita lawan mereka" sehingga mendorong gelombang pasang patriotisme seluruh warga negara yang mengalami trauma. Tahap ini mirip dengan tipikal dari era Perang Dingin yang membagi dunia menjadi dua kekuatan yaitu Amerika Serikat dan Uni Soviet yang kemudian berkembang menjadi "sisi kita versus pandangan mereka" 
Untuk menunjukkan fenomena ketakutan pada limbic war di media, ia meneliti beberapa tajuk utama yang muncul di Los Angeles Times antara Desember 1941 hingga Februari 1942 dan juga melakukan survei di dalam tajuk berita utama yang diterbitkan The New York Times antara September 2001 dan Desember 2002. Setelah dibandingkan, dia menemukan hasil yang hampir sama. Dari hasil penelitiannya, dia berargumen bahwa narasi umum pers Amerika sangat menakutkan secara psikologis.

Praktik politik dengan membangkitkan ketakutan publik, melalui penyajian statistik yang menakutkan, berkali-kali lipat memiliki efek luar biasa ketika digabungkan dengan kecenderungan sebagian besar masyarakat yang gelisah sehingga mulai memiliki asumsi berlebihan terhadap risiko. Steven Heller menggali lebih dalam kegunaan politik ketakutan dengan memeriksa isi propaganda yang membangkitkan emosi, menempatkan fokus khusus pada media, dan citra perang. Propaganda adalah upaya yang sangat jelas oleh para elit politik dan militer untuk memanipulasi sentimen publik. Ia menganalisis penggunaan gambar visual dari suatu musuh dan isi propaganda masa perang yang dirancang untuk membangkitkan rasa takut. Propaganda memberikan bentuk pengaruh eksternal secara terangterangan yang dirancang untuk membangkitkan rasa takut dan menciptakan permusuhan, konsisten dengan efek khas dari sebuah ancaman. ${ }^{40}$

Aksi-aksi kekerasan terorisme adalah sebuah fenomena dalam berkomunikasi. Simbol terorisme tidak hanya didominasi oleh bom, penculikan, atau aksi-aksi brutal lainnya. Terorisme saat ini dirancang untuk mengirim alarm kepada para korban dan menciptakan ketakutan yang meluas kepada mereka yang juga tidak berada di lokasi aksi terorisme. Dalam media komunikasi zaman ini, aksi terorisme sekecil apapun dapat dibuat dramatis dan meluas ke area publik. ${ }^{41}$

Penderitaan mental menjadi bagian utama teror, tidak hanya bagi individu atau kelompok manusia yang mengalaminya, melainkan dapat menyebar ke banyak orang di tempat lain melalui pesan atau gambar. Hal senada juga disampaikan oleh Bruce Hoffman, sarjana terkemuka studi terorisme Amerika. Dia mendefinisikan terorisme sebagai eksploitasi dari rasa takut yang disengaja melalui kekerasan atau ancaman kekerasan dalam perjuangan politik. $^{42}$

40. Leonie Huddy, "Fear and How It Works: Science and the Social Sciences," Social Research 71, no. 4 (2004): 803.

41. Winkler, In the Name of Terrorism, 189.

42. Falk, "Terrorism: Agreeing on the Basics. 
Prinsip kekuasaan dalam dunia modern adalah mengendalikan negara. ${ }^{43}$ Segelintir penguasa mengeksploitasi nasionalisme dan memobilisasi komunitas melenggangkan kekuasaan para elit. ${ }^{44}$ Para elit telah berhasil melebur bersama tradisi nasionalisme agar kekuasaan mereka bertahan dengan cara menunggangi pergerakan nasionalis. ${ }^{45}$ Keberhasilan pergerakan nasionalis dalam mengakomodasi keluhan-keluhan rakyat yang selama ini tertindas oleh sistem hirarki merupakan prasyarat penting keberhasilan mobilisasi gerakan. Namun, keberhasilan menanamkan ideologi subversif dan memobilisasi rakyat dijadikan instrumen bagi para elit menyalurkan keserakahan mereka untuk mengubah tatanan sosial dan politik. ${ }^{46}$

Pada perkembangannya, nasionalisme didefinisikan sebagai ideologi yang mendudukkan sebuah bangsa menjadi perhatian utama di dalam mengusahakan kesejahteraan rakyatnya. ${ }^{47}$ Usaha-usaha tersebut memiliki tujuan utama yang pada umumnya terbagi tiga antara lain kedaulatan, kesatuan, dan identitas nasional. Bagi para nasionalis, sebuah bangsa tidak akan bertahan apabila ketiga tujuan utama di atas tidak tercapai. Hal ini membentuk sebuah definisi nasionalisme yakni sebuah ideologi yang terus menerus mengupayakan dan menjaga kedaulatan, kesatuan, dan identitas nasional.

Namun, ide sebuah bangsa (nation) telah ditaburkan di tanah Asia dan Afrika atas nama imperialisme dan kolonialisme yang begitu menimbulkan kebencian. Kemiskinan serta bekas luka penjajahan secara fisik dan psikologis, yang bertahan lama era pascaperang dapat dikaitkan dengan imperialisme. Orang-orang Eropa, yang didorong gelombang pencerahan intelektualnya, berbondong-bondong menuju daratan Afrika dan Asia untuk mencari sumber daya alam atau bahan mentah untuk memenuhi kebutuhan ekonomi. Kolonialisme sudah dimulai pada awal abad $15 .{ }^{48}$ Kebencian, dengan logika biner antara kita dan mereka atau jahat dan baik, kemudian dipupuk selama Perang Dingin. Apa yang terjadi pada paruh pertama abad ke-20 meninggalkan jejak yang tak terhapuskan bagi para pemimpin dan gagasan yang mereka proyeksikan ke negara mereka.

43. Abdul Basit Khan, et al., A Comparative Study of the Philosophical Evolution of the Doctrines of 'Nation' and 'Nationalism', Pakistan Journal of Social Science 39:2 (2019): 360.

44. Ibid.

45. Ibid., 360-361.

46. Anthony Smith, The Nation in History: Historiographical Debates about Ethnicity and Nationalism (Oxford: Polity Press: 2000), 58-59.

47. Smith, Nationalism: Theory, Ideology, History, 9.

48. Khan, "Doctrines of 'Nation' and 'Nationalism'," 353. 
Kebencian yang disemai di tanah imperialisme memberi andil melanggengkan kekerasan-kekerasan lain. Kedaulatan, kesatuan, dan identitas nasional yang sudah didapat dengan susah payah dan diusik oleh negara lain ataupun gejolak di dalam negeri dengan sendirinya memicu eskalasi konflik. Perlahan, nasionalisme mewujud ke dalam bentuk yang eksklusif dan agresif. ${ }^{49}$

Di Indonesia sendiri, nasionalisme mengalami banyak perubahan dan pembentukan di bawah rezim Orde Baru. Pemerintah, yang pada saat itu dalam transisi, menggunakan instrumen "ketakutan" untuk memperkuat legitimasi pemerintahannya. Nasionalisme terbentuk melalui kultur rezim yang mengutamakan stabilitas sosial. Dengan menggunakan aparat intelijen dan bersenjata, penguasa Orde Baru memberangus orang-orang yang berideologi Kiri maupun Liberal dengan memberi label antiideologi negara dan sebutan bukan orang Indonesia. Kondisi tersebut menimbulkan konsekuensi pada tidak adanya ruang bagi separasi kekuasaan, oposisi dalam tataran politik praktis, serta pendapat yang berbeda dari mayoritas. ${ }^{50}$

Istilah balkanisasi, yang didengungkan dalam narasi nasionalisme, juga mengalami pendangkalan makna (jika bukan penyempitan makna). Dikatakan dangkal karena istilah balkanisasi berhenti pada perpecahan yang hanya dilihat dari luarnya saja, sehingga seakan-akan buruk. Balkanisasi dijadikan contoh buruk sebuah perpecahan di suatu negara yang beragam suku bangsa. Pemahaman umum mengenai balkanisasi dari atas dan bawah jarang dikupas dalam forum-forum yang bertemakan nasionalisme khususnya di negara dengan beragam bangsa di dalamnya. Khusus dalam konsep balkanisasi dari bawah, kemauan sekelompok suku bangsa yang berada di satu negara dan ingin membentuk peradaban sendiri begitu mudah mendapat label pemberontak dikarenakan nasionalisme yang menuntut persatuan serta identitas nasional. Dikemas dengan narasi nasionalisme, istilah balkanisasi yang tidak utuh justru membantu penyebaran ketakutan lebih meluas, terencana, dan terorganisasi. Aksi-aksi seperti ini berpeluang menjadi tindakan terorisme.

\section{Kesimpulan}

Konsep terorisme muncul sebagai reaksi terhadap tindak kekerasan oleh suatu pihak, namun pemaknaan yang sepihak membuat konsep tersebut tereduksi hanya kepada kelompok tertentu, khususnya agama tertentu. Dalam dominasi tersebut, mereka dapat menentukan apa dan siapa yang

49. Lawrence, Nationalism: History and Theory, 5.

50. David M. Bourchier "Two Decades of Ideological Contestation in Indonesia: From Democratic Cosmopolitanism to Religious Nationalism" Journal of Contemporary Asia 49, no. 5 (2019): 715-6. 
dapat dikategorikan sebagai teroris. Berdasarkan pembedahan dengan hermeneutika radikal, reduksi ini dapat terlihat menguntungkan pihak lawannya yang mengkonstruksikan makna tersebut sedari awal dan yang memiliki kekuasaan untuk mengendalikan arah pemaknaan. Pengertian terorisme telah dibongkar dari kondisinya yang biner, yakni baik dan jahat. Tidak terjebak dengan logika tersebut, narasi terorisme terbuka luas untuk diinterpretasi. Nasionalisme menjadi perhatian lebih pada tulisan ini dalam mempengaruhi terorisme.

Lahir dari Abad Modern menyebabkan gagasan nasionalisme tidak lepas dari bangunan modernisme yang seringkali diartikan berkemajuan. $\mathrm{Di}$ satu sisi, bangunan ini dapat mendorong kesetaraan, partisipasi masyarakat, akuntabilitas dalam pemerintahan tetapi juga berpotensi besar di sisi lainnya dalam menumbuhkan sikap eksklusif, agresif, dan teror. Nasionalime seharusnya mendukung penuh hak-hak individu dalam menentukan nasibnya .

Istilah balkanisasi menjadi bagian atau "suplemen" bagi berdirinya konstruksi terorisme nasionalistis itu sendiri. Balkanisasi merupakan salah satu contoh yang tepat bagaimana istilah ini mengalami peyorasi. Pemisahan negara-bangsa bernama Yugoslavia dikunci dengan narasi utama yaitu perpecahan bangsa yang menyebabkan penderitaan, kesengsaraan, dan ekses-ekses negatif lainnya. Isu pemisahan atau penentuan kedaulatan sendiri yang terjadi pada balkanisasi seringkali diartikan sebagai hal yang buruk dalam narasi nasionalisme.

Tulisan ini tentu masih berkutat pada penggunaan nasionalisme sebagai salah satu sarana aksi terorisme demi mencapai tujuan politis. Dalam kajian selanjutnya, berbagai macam ideologi lain selain nasionalisme dan ekstremisme agama yang berpotensi menyuburkan terorisme perlu diteliti lebih dalam. Selain itu, konsepsi mengenai Balkanisasi dari atas maupun bawah menarik untuk digali lagi sehingga masyarakat mendapat narasi yang seimbang mengenai istilah balkanisasi. Hal ini bertujuan agar masyarakat menjadi lebih kritis dan melawan terorisme dalam bentuk apapun. 